\title{
Antimicrobial and antibiofilm activities of phenolic compounds extracted from Populus nigra and Populus alba buds (Algeria)
}

\author{
Boumghar Nassima ${ }^{\oplus 1, *}$ Behidj Nassima1 ${ }^{1}$ Ksouri Riadh² \\ ${ }^{1}$ Université M'Hamed Bougara de Boumerdès. Laboratoire de Technologies Douces, Valorisation, Physico-Chimie des \\ Matériaux Biologiques et Biodiversité, Faculté des Sciences, Algerie, ${ }^{2}$ Laboratory of Aromatic and Medicinal Plants, \\ Biotechnology Center of Borj-Cedria, Hammam-lif, Tunisia
}

\begin{abstract}
The interest of this work is the discovery of new antimicrobial agents of plant origin to inhibit the formation of microbial biofilms. The present research was conducted to identify and quantify the phenolic compounds extracted from Populus nigra and Populus alba buds harvested in the area of TiziOuzou (Algeria), and to evaluate their antimicrobial and antibiofilm activity. High performance liquid chromatography (HPLC) was performed to identify the phenolic compounds in the ethyl acetate fraction of $P$. nigra and the methanolic extracts of $P$. nigra and $P$. alba. The antimicrobial activity of the crude extracts and the fractions of these two species was tested against 11 microorganisms, using the disk diffusion method, while the antibiofilm effect of certain extracts was carried out in a 96-well microplate and on a biomaterial (catheter). HPLC analysis revealed the presence of 10 bioactive compounds. The main phenolic compounds identified in the three extracts were p-coumaric acid, ellagic acid, and Kaempferol. This study was able to demonstrate that the extracts of $P$. nigra and $P$. alba buds have interesting antimicrobial properties, with diameters ranging from 6.6 to $21.3 \mathrm{~mm}$. In addition, extracts of P. nigra exhibited antibiofilm effects greater than $70 \%$. Our results provide evidence for the antimicrobial and antibiofilm potential of bud extracts from both poplar species. Thus, these results will pave the way for further research on these two plants.
\end{abstract}

Keywords: Populus nigra. Populus alba. HPLC. Polyphenols. Antimicrobial activity. Antibiofilm activity.

\section{INTRODUCTION}

Biofilms are a community of microorganisms incorporated in a matrix of organic polymers that adhere to a surface (Carpentier, Cerf, 1993; Costerton et al., 1999; Mah, O’Toole, 2001). The organization of microbial communities of biofilms into functional consortium and the nature of the surface are specified (Costerton et al., 1995). These bacteria can adhere to inert or living surfaces, and interface with one another. It is estimated that more than $99 \%$ all of the microorganisms find themselves in a wide range of ecosystems in biofilms, making bacteria stronger and more efficient in facing the hostile environment in which they develop, compared to bacteria evolving under planktonic shape (Costerton et al., 1987; Lewis, 2001; Donald, Costerton, 2002). Bacterial organization into

\footnotetext{
*Correspondence: B. Nassima. Université M'Hamed Bougara de Boumerdès, Laboratoire de Technologies Douces, Valorisation, Physico-Chimie des Matériaux Biologiques et Biodiversité, Faculté des Sciences. Phone: +213668433583. E-mail: nassima.boumghar@yahoo.fr
}

biofilms presents a major source of sanitary, industrial, and ecological problems (Gilbert et al., 2002). It is important to note that once that a biofilm is formed, the bacteria are protected against immune defence systems and treatments, whether physical or chemical, such as disinfectants, detergents, and antibiotics. Currently, several questions have been raised regarding the safety and effectiveness of chemicals used in medicine. For more than twenty years, many determinants of resistance have been described with the appearance of increasingly resistant microbial strains (Alekshun, Levy, 2007). The regular and inappropriate use of antibiotics has led to the strong adaptation of bacterial strains and the selection of multi-resistant strains; this has consequences for human health (Kokkiligadda et al., 2013; Pasca et al., 2017). In the face of this phenomenon, jeopardized by the emergence of multi-resistant germs, interest in medicinal plants has developed because of their therapeutic properties and natural compounds that have been shown to exhibit antimicrobial and antibiofilm activities. 
The aim of the present work was to evaluate the antimicrobial and antibiofilm effects of Populus nigra and Populus alba extracts. Some studies have demonstrated the antibacterial and antifungal effects of $P$. nigra extracts. However, the activity of $P$. alba extracts has not yet been evaluted. In addition, no report regarding the antibiofilm activity of these two species is available.

\section{MATERIAL AND METHODS}

\section{Plant material}

The buds of $P$. nigra and $P$. alba were harvested in February 2015 in the region of Tizi-Ouzou, Algeria. The botanical identification of plant material was carried out by a botanist from the Department of Biology, University Mouloud Mammeri, Tizi-Ouzou (Algeria). The plant material collected was dried in the shade at an atmospheric humidity of $40 \%$ for 15 days, and then crushed into powder for analysis.

\section{Preparation of plant extracts}

The polyphenols of the buds of the two Poplar species were extracted by maceration as described by Romani et al. (2006) and Benhammou et al. (2008), with some modifications. Crushed plant material (5 g) was macerated in $100 \mathrm{~mL}$ of an organic solvent of different polarity (methanol, ethanol, ethyl acetate). After $24 \mathrm{~h}$, the samples were filtered through a filter paper (Whatman No.1). Then, the filtrates were gathered and evaporated to dryness using a rotavapor (Buchi R-200) at $40^{\circ} \mathrm{C}$.

For fractionation, the powder was macerated with acetone/distilled water (35/15, V/V). The aqueous phase obtained following removal of the solvent (acetone) was then separated sequentially with hexane, dichloromethane, ethyl acetate, and n-butanol. The dichloromethane (DF), ethyl acetate (AF), n-butanol (BF), and aqueous (AqF) fractions were collected separately and dried using a rotavapor. The recovered extracts were stored at $4{ }^{\circ} \mathrm{C}$ until further examination (Derbel et al., 2010).

\section{Determination of phenolic compounds by HPLC}

The identification of phenolic compounds was performed using HPLC. The HPLC system consists of a vacuum degasser, an autosampler, and a binary pump with a maximum pressure of 400 bar (Agilent 1260, Agilent Technologies, Germany) equipped with a reversed phase $\mathrm{C} 18$ analytical column of $4.6 \times 100 \mathrm{~mm}$ and $3.5 \mu \mathrm{m}$ particle size (Zorbax Eclipse XDB C18). The
DAD detector was set to a scanning range of $200-400 \mathrm{~nm}$. Column temperature was maintained at $25^{\circ} \mathrm{C}$. The injected sample volume was $2 \mu \mathrm{l}$ and the flow-rate of the mobile phase was $0.4 \mathrm{~mL} / \mathrm{min}$. Mobile phase B was milli-Q water with $0.1 \%$ formic acid and mobile phase A was methanol. The optimized gradient elution was as follows: $0-5 \mathrm{~min}$, 10-20\% A; 5-10 min, 20-30\% A; 10-15 min, 30-50\% A; $15-20 \mathrm{~min}, 50-70 \% \mathrm{~A} ; 20-25 \mathrm{~min}, 70-90 \% \mathrm{~A} ; 25-30 \mathrm{~min}$, 90-50\% A; 30-35 min, return to initial conditions.

For quantitative analysis, a calibration curve was obtained by plotting the peak area against different concentrations for each identified compound at $280 \mathrm{~nm}$. The obtained curves for all identified compounds showed a good linearity with an average of $r^{2}=0.99$.

\section{DETERMINATION OF ANTIMICROBIAL ACTIVITY}

\section{Microbial strains}

The antimicrobial activity of extracts of $P$. nigra and $P$. alba was tested against 11 microorganisms including nine bacteria; six Gram-positive bacteria, namely Staphylococcus aureus ATCC 29213, S. aureus ATCC 6538, $S$. aureus resistant to methicillin ATCC 43300, Enterococcus faecalis ATCC 29212, Bacillus subtilis ATCC 6633, and Listeria innocua Clip 74915; and three Gram-negative bacteria, including Escherichia coli ATCC 9029, E. coli ATCC 25922, and Pseudomonas aeruginosa ATCC 27853. For both yeasts, we used Candida albicans ATCC 10231 and Saccharomyces cerevisiae ATCC 9763. The bacterial and fungal strains were obtained from the Research and Development Center (CRD SAIDAL) in El-Harrach (Algeria) and the Laboratory of Biomathematics Biophysics Biochemistry and Scientometry (BBBS) of the University of Bejaia (Algeria).

\section{Agar diffusion test}

Pre-culture of the microbial strains was prepared by selection and culture of one colony of each species on an agar surface to reach exponential growth phase. From this culture, a quantity of the bacterial strain was suspended in sterile physiological water.

The optical densities were then adjusted using a UV spectrophotometer (Optizen pop, Koria) at a wavelength of $625 \mathrm{~nm}\left(\lambda=0.08-0.1\right.$, corresponding to $10^{8}$ colony forming units [CFU] $\mathrm{mL}^{-1}$ ) for bacteria and $530 \mathrm{~nm}$ $\left(\lambda=0.12-0.15\right.$, corresponding to $\left.1-5 \times 10^{6} \mathrm{CFU} \mathrm{mL}^{-1}\right)$ for the yeasts. The standardized inoculum $\left(10^{6} \mathrm{CFU} \mathrm{mL}^{-1}\right.$ 
for yeasts and bacteria) was streaked with a swab on Mueller-Hinton agar (Condapanadise, Spain) for bacteria or Mueller-Hinton agar supplemented with $2 \%$ glucose and $0.5 \mu \mathrm{g} \mathrm{mL}^{-1}$ methylene blue for yeasts (Testore et al., 2004; Epsinel-Ingroff, 2007). Then, 6 mm diameter filter paper discs impregnated with $10 \mu \mathrm{L}$ of solubilized extract in dimethyl sulphoxide (DMSO; 1 $\mathrm{mg} / \mathrm{disc}$ ) were deposited on the surface of the previously inoculated agar using sterile forceps. The petri dishes were left for $1 \mathrm{~h}$ at room temperature for pre-diffusion of the substances, before being incubated at $37^{\circ} \mathrm{C}$ for 18-24 h for bacteria (Adesokan, Akanji, Yakubu, 2007), and at $30{ }^{\circ} \mathrm{C}$ for $48 \mathrm{~h}$ for the yeasts. Control disks were included in the tests. The disks were impregnated with DMSO (Biochem, India) and antibiotics (gentamicin). The experiment was performed in triplicate. Antibacterial activity was determined by measuring the diameter of the inhibition zones around the disks (Doughari, Pukuma, De, 2007). The effect of the extracts was evaluated according to the criterion of Tekwu, Pieme, and Beng (2012). Thus, a substance is said to be inactive if the diameter of the zone of inhibition is less than $7 \mathrm{~mm}$, while it is said weakly active if the diameter is between 7 and $10 \mathrm{~mm}$. On the other hand, it is deemed moderately active when the diameter is greater than $10 \mathrm{~mm}$ and less than $15 \mathrm{~mm}$. It is significantly active when the diameter is greater than $16 \mathrm{~mm}$.

\section{DETERMINATION OF ANTIBIOFILM ACTIVITY}

\section{Antibiofilm activity in a 96-well microplate}

The anti-adherent properties of the methanolic and ethanolic extracts of $P$. nigra and $P$. alba on $S$. aureus ATCC 6535 and methicillin-resistant $S$. aureus (MRSA) were evaluated as described by Saising et al. (2012) with some modifications. The sterile microtiter plates were prepared by dispensing $100 \mu \mathrm{L}$ of Brin Heart Infusion Broth (BHI) with $2 \%$ glucose $\left(\mathrm{p} \mathrm{v}^{-1}\right)$ into each well. From the mother solution of extracts tested at a concentration of $20 \mathrm{mg} \mathrm{mL}^{-1}, 100 \mu \mathrm{L}$ was added to the second row of the microplate. Seven serial dilutions were then made using a micropipette, thus $100 \mu \mathrm{L}$ of overnight cultures $\left(37^{\circ} \mathrm{C}\right)$ of the tested strains diluted to $10^{6} \mathrm{CFU} \mathrm{mL}^{-1}$ in fresh BHI with $2 \%$ glucose was transferred to each well. The cultures were added to the wells in triplicate, and a growth control (cells + broth), media control (single broth), and white control (broth + extract) were included. Following incubation at $37^{\circ} \mathrm{C}$ for $24 \mathrm{~h}$ without shaking, the culture supernatant was discarded. Then, each well was washed twice with phosphate-buffered saline (PBS) to remove loosely associated cells. The plates were dried in the oven at $60{ }^{\circ} \mathrm{C}$ for $30 \mathrm{~min}$. After drying, the surfacefixed cells were stained with $200 \mu \mathrm{L}$ of $0.1 \%$ violet crystal. Quantitative evaluation of biofilm cells was estimated by solubilisation of the dye with $200 \mu \mathrm{L}$ of $96 \%$ ethanol, and the optical density (OD) was determined at $570 \mathrm{~nm}$ using a UV spectrophotometer (Optizen pop). The percent inhibition of the biofilm was calculated using the following formula: [(OD growth control - OD sample) / OD growth control] $\times 100$ (Chaieb et al., 2011).

\section{Antibiofilm activity on the biomaterial}

In vitro experiments evaluated the ability of the extracts of $P$. nigra and $P$. alba to inhibit biofilm formation on catheter tubes. Briefly, sterile pieces of a $1 \mathrm{~cm}$ intravenous infusion tube were incubated with $100 \mu \mathrm{L}$ of bacterial suspension and $100 \mu \mathrm{l}$ of extract at different concentrations $\left(20-0.156 \mathrm{mg} \mathrm{mL}^{-1}\right)$ in a microplate. After incubating the plates at $37^{\circ} \mathrm{C}$ for $24 \mathrm{~h}$, the catheter pieces were washed twice with PBS, dried, and stained with $200 \mu \mathrm{L}$ of $0.1 \%$ crystalline violet. Biofilm biomass was determined by the crystal violet colorimetric method as described above.

\section{RESULTS AND DISCUSSION}

HPLC separation of the phenolic compounds from the methanolic extract of P. nigra and P. alba and the AF of $P$. nigra is presented in Figure 1, and the concentrations are shown in Table I. The separation detected the presence of p-coumaric acid $(\operatorname{Tr}=20 \mathrm{~min}$, peak 1$)$, myricitrin $(\mathrm{Tr}=20.7 \mathrm{~min}$, peak 2$)$, luteolin-7-O-glucoside $(\operatorname{Tr}=21.1 \mathrm{~min}$, peak 3$)$, rosmarinic acid $(\operatorname{Tr}=21.7 \mathrm{~min}$, peak 4), ellagic acid $(\operatorname{Tr}=22.2 \mathrm{~min}$, peak 5), quercetin $(\mathrm{Tr}=23.7 \mathrm{~min}$, peak 6$)$, naringenin $(\mathrm{Tr}=24.2 \mathrm{~min}$, peak 7), luteolin $(\operatorname{Tr}=24.8 \mathrm{~min}$, peak 8$)$, kaempferol $(\mathrm{Tr}=25.5 \mathrm{~min}$, peak 9$)$, and apigenin $(\mathrm{Tr}=25.8 \mathrm{~min}$, peak 10) in the extracts tested.

The HPLC fingerprinting of $P$. nigra and $P$. alba extracts revealed a difference in the phenolic composition of the samples. Several compounds identified in the AF, namely luteolin, luteolin 7-O-glucoside, naringenin, and apigenin, were not found in the other extracts. Rosmarinic acid and quercetin were only detected in the methanolic extract of $P$. nigra. Chromatographic analysis also showed that there is a difference in all peak intensities. This suggests the existence of a different content of phenolic compounds in the tested samples: all extracts contained ellagic acid, kaempherol, and p-coumaric acid, although 
TABLE I - Identification of phenolic compounds in P. nigra and P. alba buds extracts

\begin{tabular}{|c|c|c|c|c|c|}
\hline \multirow{2}{*}{ peaks } & \multirow{2}{*}{ Compounds } & \multirow{2}{*}{$\begin{array}{l}\text { Retention time } \\
\quad(\mathrm{min})\end{array}$} & \multicolumn{3}{|c|}{ Quantity ( $\mathrm{mg} \mathrm{g}^{-1}$ of residue ) } \\
\hline & & & AF.Pn & ME.Pn & ME. Pa \\
\hline 1 & $p$-coumaric acid & 20 & 2.47 & 1.73 & 0.50 \\
\hline 2 & Myricitrin & 20.7 & 13.42 & nd & nd \\
\hline 3 & Luteolin7-O-glucoside & 21.1 & 39.86 & nd & nd \\
\hline 4 & rosmarinic acid & 21.7 & nd & 14.46 & nd \\
\hline 5 & ellagic acid & 22.2 & 1.79 & 1.98 & 1.79 \\
\hline 6 & Quercetin & 23.7 & nd & 2.07 & nd \\
\hline 7 & Naringenin & 24.2 & nd & nd & nd \\
\hline 8 & Luteolin & 24.8 & 10.81 & nd & nd \\
\hline 9 & Kaempferol & 25.5 & 6.20 & 5.17 & 0.54 \\
\hline 10 & Apigenin & 25.8 & 1.12 & nd & nd \\
\hline
\end{tabular}

Legend: AF.Pn = Ethyl acetate fraction of Populus nigra; ME.Pn = methanolic extract of Populus nigra; $\mathrm{ME} . \mathrm{Pa}=$ methanolic extract of Populus alba; $\mathrm{nd}=$ non detected

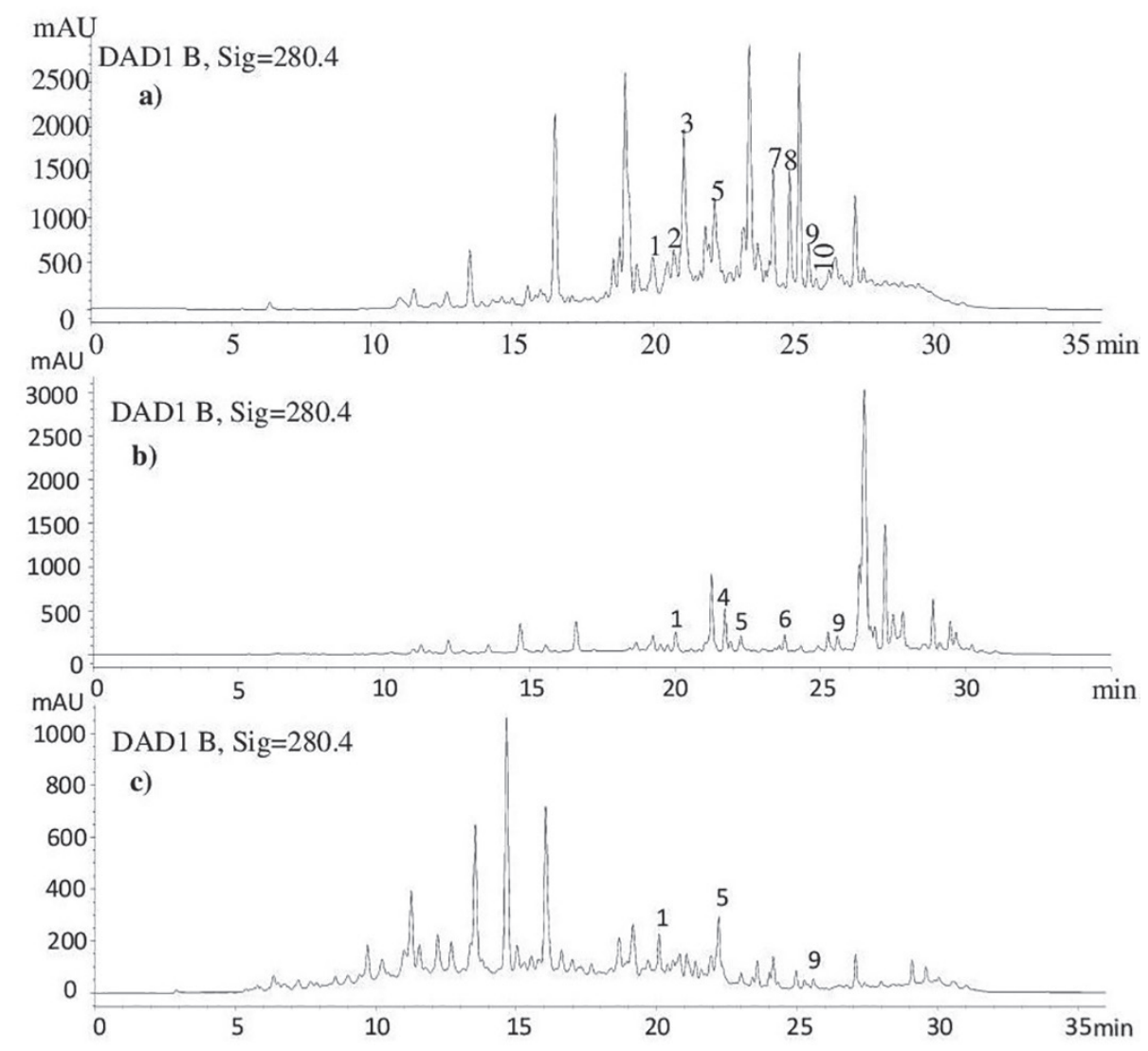

FIGURE 1 - Chromatographic profiles acquired at $280 \mathrm{~nm}$ of poplar extracts. (a) Ethyl acetate fraction of P. nigra (AF.Pn). (b) methanolic extract of P. nigra (ME.Pn). (c) methanolic extract of P. alba (ME.Pa). Peaks numbers are referred to those reported in Table I.

the highest concentration was observed for the AF. The work of Falcao et al. (2010) also showed the presence of p-coumaric acid and apigenin in poplar-type propolis.
Some peaks of the obtained chromatograms were not determined because of the unavailability of certain standards. 
The in vitro antimicrobial activity of 13 extracts against 11 reference microbial strains tested in this present study was qualitatively evaluated by the presence or absence of inhibition zone (IZ) diameter. The crude extracts of $P$. alba showed moderate activity against Gram-positive bacteria, including S. aureus ATCC 29213, $S$. aureus ATCC 6538, MRSA, E. frendii, and L. Innocua (Table II). Low activity was recorded against Gramnegative bacteria, namely E. coli ATCC 25922, E. coli ATCC 8739 , and $P$. aeruginosa, while no effect was observed with C. albicans and S. cerevisiae.

It should be noted that the fractions stemming from white poplar buds have a moderate inhibitory effect on the growth of Gram-positive bacteria. In fact, the highest inhibition was recorded for the AF against $S$. aureus ATCC 6538 and L. innocua with an IZ diameter of 18.33 and $19 \mathrm{~mm}$, respectively.

With respect to the organic extracts of black poplar (ME, EE, and AE), the S. aureus ATCC 29213 and MRSA strains express a high sensitivity toward these extracts with the following IZ diameters: 21.3 and 17.83, respectively, for the ME, 17.5 and 16.33, respectively, for the EE, and 17 and 17.83 , respectively, for the AE. Low sensitivity was observed for E. coli ATCC 25922, E. coli ATCC 25922,
E. coli ATCC 8739, and P. aeruginosa.

For the fractions derived from the methanolic extract of $P$. nigra, we noticed that the AF and DF exerted greater activity against $S$. aureus ATCC 29213, SARM, and L. innocua with an IZ diameter of 20, 18.3, and 17.66 $\mathrm{mm}$, respectively, for the $\mathrm{AF}$, and of $18,19.5$, and $16 \mathrm{~mm}$, respectively, for the DF. However, the $\mathrm{AqF}$ gave results that varied from 6.6 to $8.16 \mathrm{~mm}$ in diameter, which reflects little to no activity.

According to the current results, the fractions and crude extracts of the buds of the two species studied present antimicrobial activity against all of the microorganisms studied. Thus, the IZ diameters were between 6.6 and $21.3 \mathrm{~mm}$. In addition, $S$. aureus ATCC 29213, S. aureus ATCC 6538, and B. subtilis have been considered the most sensitive. These results are in agreement with those of Vardar-Ünlü et al. (2008).

Compared to gentamicin, the methanolic and ethanolic extracts have a greater effect on $E$. faecalis, and in the case of $S$. aureus ATCC 6538, it was the methanolic extract of $P$. nigra and the AF of $P$. alba that were more effective.

In general, the results show that $P$. nigra extracts possess a potent antibacterial activity compared to $P$. alba

TABLE II - Antimicrobial activity of differents extracts through diffusion method on a solid medium

\begin{tabular}{|c|c|c|c|c|c|c|c|c|c|c|c|c|}
\hline & \multirow{3}{*}{$\begin{array}{l}\text { Extracts } \\
\text { (1mg/disk) }\end{array}$} & \multicolumn{11}{|c|}{ Inhibition zone diameter $(\mathrm{mm})$ * } \\
\hline & & \multicolumn{6}{|c|}{ Gram positive bacteria } & \multicolumn{3}{|c|}{ Gram negative bacteria } & \multicolumn{2}{|c|}{ Levures } \\
\hline & & $E f$ & Sa1 & $\mathrm{Sa2}$ & SARM & Bs & $L i$ & Ec1 & $E c 2$ & $P s$ & $C a$ & $S c$ \\
\hline \multirow[t]{7}{*}{$\begin{array}{l}\text { Populus nigra } \\
\text { (Pn) }\end{array}$} & $\mathrm{ME}$ & 11.33 & 21,3 & 16.16 & 17.83 & 15,33 & 9.33 & 7.66 & 8,66 & 7.50 & 11 & 9 \\
\hline & $\mathrm{EE}$ & 11.66 & 17.5 & 15 & 16.33 & 12 & 8.83 & 7 & 8 & 7.33 & 12 & 10.66 \\
\hline & $\mathrm{AE}$ & 11 & 17 & 14.83 & 17.66 & 13 & 11.66 & 7 & 7.6 & 7 & 13.66 & 10.33 \\
\hline & DF & 9 & 18 & 12 & 19,5 & 12.33 & 16 & 8 & 7.5 & 8.33 & 12.33 & 10.33 \\
\hline & $\mathrm{BF}$ & 10 & 10,33 & 12.5 & 14 & 15.33 & 11 & 7 & 6 & 6.5 & 7.8 & 8.33 \\
\hline & $\mathrm{AF}$ & 10.33 & 20 & 14 & 18.33 & 16 & 17.66 & 7.66 & 8.5 & 7 & 9.66 & 8 \\
\hline & $\mathrm{AqF}$ & 6.6 & 8,16 & 10.5 & 7 & 9 & 8 & $\mathrm{Na}$ & $\mathrm{Na}$ & $\mathrm{Na}$ & $\mathrm{Na}$ & $\mathrm{Na}$ \\
\hline \multirow[t]{6}{*}{ Populus alba $(\mathrm{Pa})$} & $\mathrm{ME}$ & 12 & 16.33 & 14.16 & 14 & 12.66 & 16.33 & 8.66 & 9.6 & 9.66 & $\mathrm{Na}$ & $\mathrm{Na}$ \\
\hline & $\mathrm{EE}$ & 12.66 & 13 & 13.16 & 11.33 & $\mathrm{Na}$ & 12.33 & 8 & 9 & 9 & $\mathrm{Na}$ & $\mathrm{Na}$ \\
\hline & DF & 7.33 & 11 & 11 & 9.66 & 8.66 & 11 & 8 & $\mathrm{Na}$ & 7.33 & 8.33 & 8 \\
\hline & $\mathrm{BF}$ & 11.33 & 13.33 & 13.33 & 10.63 & 12 & 15.6 & $\mathrm{Na}$ & 10.66 & 7.16 & $\mathrm{Na}$ & $\mathrm{Na}$ \\
\hline & $\mathrm{AF}$ & 8.66 & 12.66 & 18.33 & 13.5 & 11.33 & 19 & 9.66 & 9 & 8.33 & $\mathrm{Na}$ & 8 \\
\hline & $\mathrm{AqF}$ & 9 & 9 & 11.66 & 8 & 7 & 8.5 & $\mathrm{Na}$ & $\mathrm{Na}$ & 7 & $\mathrm{Na}$ & $\mathrm{Na}$ \\
\hline$\overline{\mathrm{G}(15 \mu \mathrm{g} / \text { disk })}$ & & 10 & 21 & 15 & 18 & $\mathrm{Nt}$ & 29 & 20 & 15 & 9 & 18 & 16 \\
\hline
\end{tabular}

Legend: "*"=The diameter of the inhibition zone around the filter paper discs $(6 \mathrm{~mm}) ; \mathrm{Na}=\mathrm{No}$ activity; $\mathrm{Nt}=\mathrm{No}$ tested; $\mathrm{ME}=$ Methanolic extract; $\mathrm{EE}=$ Ethanolic extract; $\mathrm{AE}=$ Ethyl acetate extract; $\mathrm{DF}=$ Dichloromethane fraction; $\mathrm{BF}=\mathrm{n}-\mathrm{butanol}$ fraction; $\mathrm{AF}=$ Ethyl acetate fraction; $\mathrm{AqF}=$ Aqueous fraction, $\mathrm{G}=$ Gentamicin. Sa1=S. aureus ATCC 29213; Sa2 = S. aureus ATCC 6538; Ec1=E. coli ATCC 8739; Ec2 = E. coli ATCC 25922. 
extracts. The AF had a significant effect, and the DF exerts an antimicrobial effect too restricted on all microorganisms tested. This shows that the bioactive compounds are less soluble in this solvent. These results are consistent with those of Abu-shanab et al. (2004), Owolabi, Omogbai, and Obasuyi (2007), and Valarmathy et al. (2010). These studies reported a sensitivity of bacterial strains to organic extracts compared with the aqueous extract.

Analysis of the experimental data revealed that organic extracts were more effective against Gram-positive than Gram-negative bacteria. Gram-negative bacteria are highly resistant, and this resistance is likely related to the nature of their outer membranes, which are impervious to lipophilic compounds (Djenane et al., 2012). Grampositive bacteria are more sensitive and less protected against polyphenolic agents because they only have an outer layer of peptidoglycans, which can only prevent the diffusion of molecules whose molar mass is greater than 50000 D (Hogan, Kolter, 2002; Abirami, Gomathinayagam, Panneerselvam, 2012). Smith-Palmer, Stewart, and Fyfe (1998), Marino, Bersani, and Comi (1999) and Inouye, Takizwa, and Yamaguchi (2001) obtained similar results to those of the present study, supporting the hypothesis that Gram-positive bacteria are more sensitive to plant extracts.

In a recent study, Vardar-Ünlü, Silici, Ünlü (2008) reported that the antimicrobial activity of an extract is likely due to the presence of synergy among various phenolic components.

Biofilms are the dominant microbial lifestyle, and are present in different environments, notably clinical, industrial, and food treatment environments, and drinking water distribution networks (Baker, Banfield, 2003; Kavanaugh, Ribbeck, 2012; Oral et al., 2010). It is important to mention that the microbial organization in biofilms is important for their virulence. This organization provides enhanced resistance to antimicrobial agents (Flowers et al., 1989), which leads to serious problems for human health (Costerton et al., 1999).

In this study, for the first time, the antibiofilm activity of methanolic and ethanolic extracts of $P$. nigra and $P$. alba against two bacteria, namely MRSA and $S$. aureus ATCC 6538, were studied. These bacteria have a great ability to form biofilms (Figure 2). The effect of the $\mathrm{AF}$ and ME prepared from the buds of these two species on the inhibition of the formation of biofilm B. substitus on a venous catheter was also examined.

Extracts of $P$. nigra and $P$. alba have shown efficient antibiofilm activity against the tested strains (Figure 3 ). Inhibition percentages greater than $70 \%$ were recorded for $P$. nigra extracts and more than $50 \%$ for $P$. alba extracts. Nevertheless, none of the extracts could inhibit biofilm formation completely.

Among the plant extracts tested, only the P. nigra extract has showed strong anti-adhesion activity, with an inhibition value of $88.64 \%$ for MRSA, while the methanolic extract of $P$. alba gave appreciable results in the inhibition of bacterial biofilms, with rates of $63.68 \%$ and $58.18 \%$ for MRSA and S. aureus ATCC 6538, respectively. Thus, MRSA is more sensitive than $S$. aureus ATCC 6538.

Evaluation of the inhibition potential of plant extracts against cell attachments to catheter tubes (Table III) showed that $P$. nigra extracts present a greater effect than $P$. alba extracts on inhibition of $B$. subtilis biofilm formation. The ethyl acetate fraction of $P$. nigrawas effective at a concentration of $0.814 \mathrm{mg} \mathrm{mL}^{-1}$, followed by the methanolic extract of $P$. nigra at $1.344 \mathrm{mg} \mathrm{mL}^{-1}$, and the methanolic extract of $P$. alba with $10.174 \mathrm{mg} \mathrm{mL}^{-1}$. The AF of $P$. alba was $11.541 \mathrm{mg} \mathrm{mL}^{-1}$.

$P$. nigra extracts were revealed to effectively inhibit biofilm formation of $S$. aureus ATCC 6538, MRSA, and B. subtilis (Table III, Figures 3 and 4). According to our observations, the antibiofilm potential against these three strains may be related to the presence of one or more bioactive compounds with pronounced antibiofilm properties. In fact, flavonoids, quercetin, kaempferol, naringenin, and apigenin are generally considered to be the compounds most responsible for this activity (Vikram et al., 2010; Cho et al., 2015). In addition, preventative action of p-coumaric on the formation of biofilms of $E$. coli in urinary catheter fragments was observed at a concentration of $0.25 \%$ and $0.5 \%$ (Kot et al., 2015).
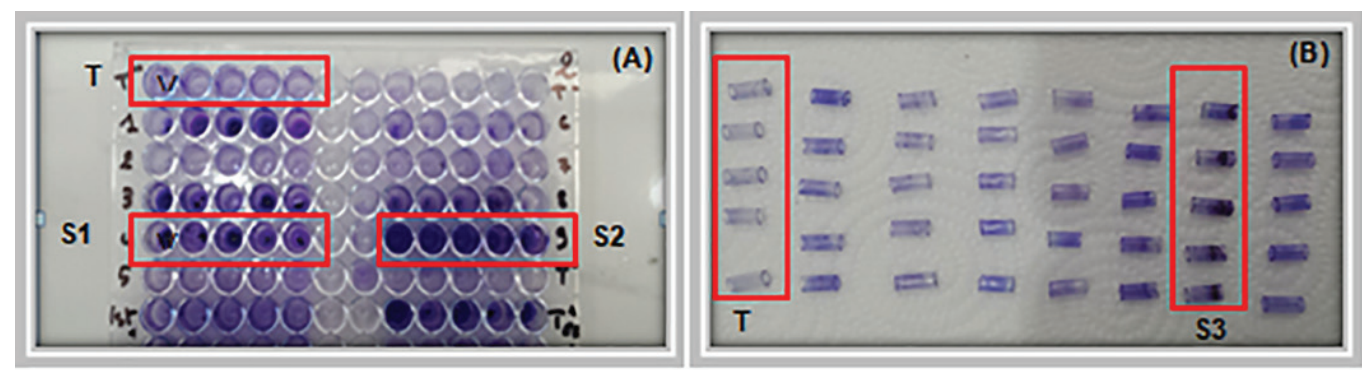

FIGURE 2 - Adhesion test of bacterial strains on a 96-wells microplate (A) and on a catheter (B). 

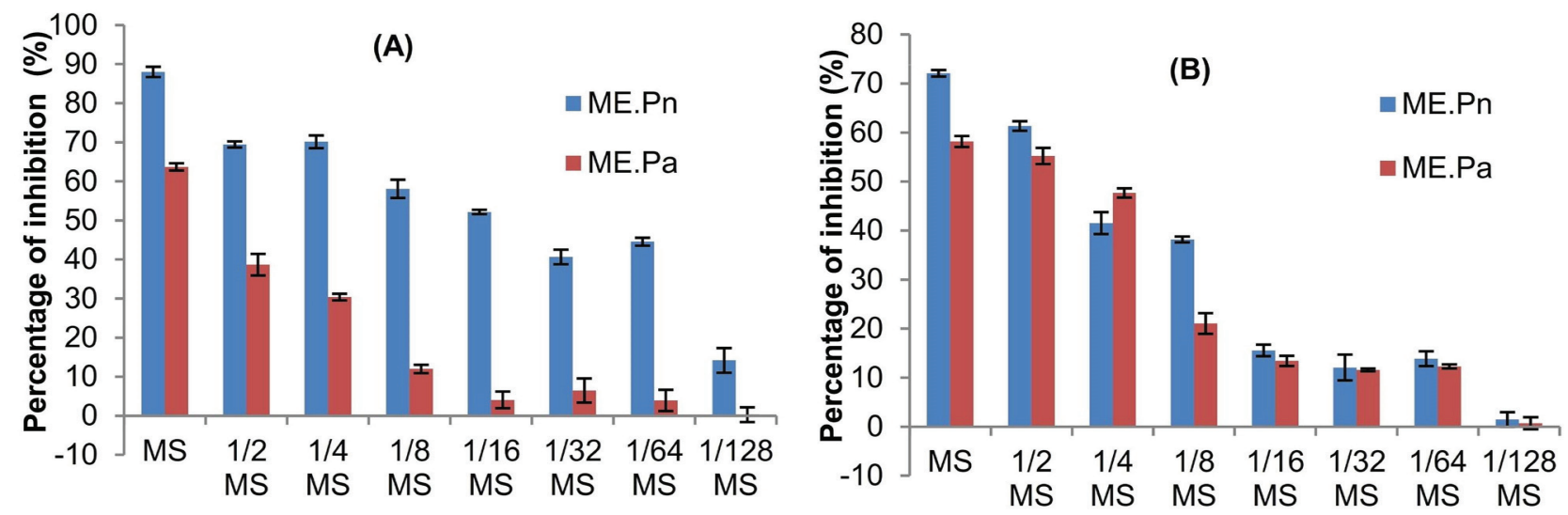

FIGURE 3 - The effect of P. Nigra methanolic extract (ME. Pn) and P. Alba methanolic extract (ME. Pa) on the attachment of methicillin resistant S. aureus (MRSA) ATCC 43300 (A) and of S. aureus ATCC 6538 (B), expressed as percentage inhibition.
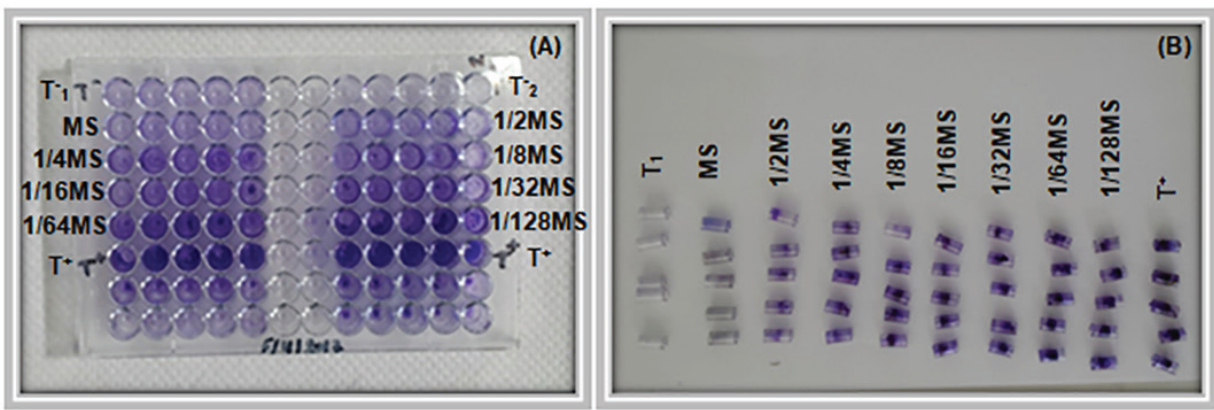

FIGURE 4 - Antibiofilm effect of methanolic extract of P. nigra (ME.Pn) on MRSA, in 96-well microplate (A), and ethyl acetate fraction of P. nigra (AF.Pn) on B. subtilis, in venous catheter (B).

TABLE III - Biofilm inhibitory concentration of ethyl acetate fraction and methanol extract of $P$. nigra and $P$. alba.

\begin{tabular}{lcccc}
\hline strain & $\begin{array}{c}\text { ME.Pn } \\
\text { BIC }_{\mathbf{5 0}}{ }^{\mathbf{a}}\end{array}$ & $\begin{array}{c}\text { AF.Pn } \\
\text { BIC }_{\mathbf{5 0}}\end{array}$ & $\begin{array}{c}\text { ME.Pa } \\
\text { BIC }_{\mathbf{5 0}}\end{array}$ & $\begin{array}{c}\text { AF.Pa } \\
\mathbf{B I C}_{\mathbf{5 0}}\end{array}$ \\
\hline Bacillus subtilis & $1.344 \pm 0.28$ & $0.814 \pm 0.81$ & $10.174 \pm 1.84$ & $11.541 \pm 0.19$ \\
\hline
\end{tabular}

Legend: $\mathrm{BIC}_{50}=$ biofilm inhibitory concentration required to reduce biofilm coverage by $50 \%$. ${ }^{\mathrm{a}}$ Data provided in $\mathrm{mg} \mathrm{mL}^{-1}$.

The results obtained in this study have revealed a promising pathway in the inhibition of biofilms by polyphenolic extracts and for the reduction of microbial colonization on epithelial surfaces and mucous membranes, which can lead to infections (Bavington, Page, 2005). Inhibition of the attachment of planktonic microbial cells to a substrate is easier than that of an already formed biofilm, due to a lack of penetration, inactivation of the drug, subpopulations of persistent strains, or the variable physiological state of microorganisms in the biofilm (Kamal et al., 1991; Oie et al., 1996; Ceri et al., 1999; Donlan, 2000; Cerca et al., 2005).

\section{CONCLUSIONS}

This study of $P$. nigra and $P$. alba buds has shown that they are a good source of biologically active compounds, which can be used in therapeutic and pharmaceutical fields due to their rich and varied composition of secondary metabolites. Moreover, extracts of these plants can serve as effective antimicrobial agents. Although the literature provides information on the use of Populus extracts for an antimicrobial effect. However, this study is one of few that addresses the antibiofilm activity of P. nigra and P. alba extracts. Thus, the inhibition of biofilm formation by the extracts revealed in this study is significant. Further complementary studies will be necessary to isolate and identify the bioactive molecules responsible for the antibiofilm activity of each extract. In addition, evaluation of antibiofilm activity in vivo will be important to determine the mechanism by which phenolic compounds affect biofilm formation. 


\section{ACKNOWLEDGEMENTS}

We thank the laboratory staff of Extremophile Plantes (Biotechnology Center of Borj-CedriaTechnopol, Tunisia) for their help in the identification of polyphenols by HPLC. We would also like to thank the team at the Research and Development Center (CRD SAIDAL) in ElHarrach (Algeria) and the Laboratory of Biomathematics Biophysics Biochemistry and Scientometry of the University of Bejaia.

\section{REFERENCES}

Abirami P, Gomathinayagam M, Panneerselvam R. Preliminary study on the antimicrobial activity of Enicostemmalittorale using different solvents. Asian Pacific J Trop Med. 2012;5(7):552-555.

Abu-shanab B, Adwan G, Abu-safiya D, Jarrar N, Adwan K. Antibacterial activities of some plant extracts utilized in popular medicine in Palestine. Turk J Biol. 2004;28:99-102.

Adesokan AA, Akanji MA, Yakubu MT. Antibacterial potentials of aqueous extract of Enantiachloranthastem bark. Afr J Biotechnol. 2007;6(22):2502-05.

Alekshun MN, Levy SB. Molecular mechanism of antibacterial multidrug resistance. Cell. 2007;128(6):1037-50.

Baker BJ, Banfield JF. Microbial communities in acid mine drainage. FEMS Microbiol Ecol. 2003;44(2):139-52.

Bavington C, Page C. Stopping bacterial adhesion: a novel approach to treating infections. Respiration. 2005;72(4):335-44.

Benhammou N, AtikBekkara F,KadifkovaPanovska T. Antioxidant and antimicrobial activities of the Pistacia lentiscus and Pistacia atlantica extracts. Afr J Pharm Pharmacol. 2008;2(2):22-28.

Carpentier B, Cerf O. Biofilms and their consequences, with particular reference to hygien in the food industry-a review. J Appl Bacteriol. 1993;75(6):499-511.

Cerca N, Martins S, Pier GB, Oliveira R, Azeredo J. The relationship between inhibition of bacterial adhesion to a solid surface by sub-MICs of antibiotics and subsequent development of a biofilm. Res Microbiol. 2005;156(5-6):650-5.
Ceri H, Olson ME, Stremick C, Read RR, Morck D,Buret A. The Calgary Biofilm Device: new technology for rapid determination of antibiotic susceptibilities of bacterial biofilms. J Clin Microbiol. 1999;37(6):1771-6.

Chaieb K, Kouidhi B, Jrah H, Mahdouani K,Bakhrouf A. Antibacterial activity of thymoquinone, an active principle of Nigella sativa and its potency to prevent bacterial biofilm formation. BMC Complement Altern Med. 2011;11(29):1-6.

Cho HS, Lee JH, Cho MH, Lee J. Red wines and flavonoids diminish Staphylococcus aureus virulence with anti-biofilm and anti-hemolytic activities. Biofouling. 2015;31(1):1-11.

Costerton JW, Cheng KJ, Geesey GG, Ladd TI, Nickel JC, Dasgupta M, Marrie TJ.Bacterial biofilms in nature and disease. Annu Rev Microbiol. 1987;41:435-64.

Costerton JW, Lewandowski Z, Caldwell D E, Korber DR, Lappin-Scot HM. Microbial biofilms. Ann Rev Microbiol. 1995;49:711-745.

Costerton J, Stewart PS, Greenberg E. Bacterial biofilms: a common cause of persistent infections. Science. 1999;284(5418):1318-22.

Derbel S, Bouaziz M, Dhouib A, Sayadi S, Chaieb M. Chemical composition and biological potential of seed oil and leaf extracts of Henophyton deserti Coss\&Durieu. Comptes Rendus Chiem. 2010;13(4):373-480.

Djenane D, Yangüela J, Derriche F, Bouarab L, Roncales P. Utilisation des composés de feuilles d'olivier comme agents antimicrobiens; application pour la conservation de la viande fraîche de dinde. Nat Technol. 2012;7:53-61.

Donlan RM. Role of biofilms in antimicrobial resistance. ASAIO J. 2000;46(6):S47-S52.

Donald RM, Costerton JW. Biofilms: survival mechanisms of clinically relevant microorganisms. Clin Microbiol Rev. 2002;15(2):167-193.

Doughari JH, Pukuma MS, De N. Antibacterial effects of Balanites aegyptiaca L. Drel. And Moringa oleifera Lam. on Salmonella typhi. Afr J Biotechnol. 2007;6(19):2212-5.

Epsinel-Ingroff A. Standardized disk diffusion method for yeasts.Clin Microbiol Newslett. 2007;29(13):97-100. 
Falcao SI, Vilas-Boas M, Estevinho LM, Barros C, Domingues MR, Cardoso SM. Phenolic characterization of North-east Portuguese propolis: usual and unusual compounds. Anal Bioanal Chem. 2010;396(2):887-97.

Flowers RH, Schwenzer KJ, Kopel RF, Fisch MJ, Tucker SI, Farr BM. Efficacy of an attachable subcutaneous cuff for the prevention of intravascular catheter-related infection.JAMA. 1989;261(6):878-83.

Gilbert P, Maira-Litran T, McBain AJ, Rickard A, Whyte F.The physiology and collective recalcitrance of microbial biofilm communities. Adv Microb Physiol. 2002;46:202-56.

Hogan D, Kolter R. Why are bacteria referactory to antimicrobials? Curr Opin Microbiol. 2002;5(5):472-77.

Inouye S, Takizwa T, Yamaguchi H. Antibacterial activity of essential oils and their major constituents against respiratory tract pathogens by gaseous contact. J Antimicr Chem. 2001;47(5):565-573.

Kamal GD, Pfaller MA, Rempe LE, Jebson PJR. Reduced intravascular catheter infection by antibiotic bonding. A prospective, randomized, controlled trial. JAMA. 1991;265(18):2364-8.

Kavanaugh NL, Ribbeck K. Selected antimicrobial essential oils eradicate Pseudomonas spp. and Staphylococcus aureus biofilms. Appl Envir Microbiol. 2012;78(11):4057-61.

Kokkiligadda S, Karlapudi PA, Indira M, Kodali VP. Biochemical and molecular characterization of biofilm producing bacteria. Int J Pharm Bio Sci. 2013;4(1B):702-12.

Kot B, Wicha J, Piechota M, Wolska K, Gruzewska A. Antibiofilm activity of trans-cinnamaldehyde, p-coumaric, and ferulic acids on uropathogenic Escherichia coli. Turk J Med Sci. 2015;45(5):919-24.

Lewis K. Riddle of biofilm resistance. Antimicrob Agents Chemother. 2001;45(4):999-1007.

Mah TFC, O'Toole GA. Mechanisms of biofilm resistance to antimicrobial agents. Trends Microbiol. 2001;9(1):34-9.

Marino M, Bersani C, Comi G. Antimicrobial activity of the essential oils of thymus vulgaris L. measured using a bioimpedometric method. J Food Prot. 1999;62(9):1017-23.
Oie S, Huang Y, Kamiya A, Konishi H, Nakazawa T. Efficacy of disinfectants against biofilm cells of methicillin-resistant Staphylococcus aureus. Microbios.1996;85(345):223-30.

Oral NB, Vatansever L, Aydin BD, Sezer C, Güven A, Gülmez, et al. Effect of oregano essential oil on biofilms formed by Staphylococci and Escherichia coli. KafkasUniv Vet FakDergisi. 2010;16(SupplA):S23-S29.

Owolabi OJ, Omogbai EKI, Obasuyi O. Antifungal and antibacterial activities of the ethanolic and aqueous extract of Kigelia africana (Bignoniaceae) stem bark. Afr J Biotechnol. 2007;6(14):1677-80.

Pasca C, Marghitas L, Dezmirean D, Bobis O, Bonta V, Chirila F, Matei I, Fit N. Medicinal plants based products tested on pathogens isolated from mastitis milk. Molecules. 2017;22(9):E1473.

Romani A, Pinelli P, Cantini C, Cimato A, HeimLer D. Characterization of Violetto di Toscana, a typical Italian variety of artichoke (Cynarascolymus L.). J Food Chem. 2006;95(2):221-5.

Saising J, Dube L, Ziebandt AK, Voravuthikunchai SP, Nega M, Götz F. Activity of Gallidermin on Staphylococcus aureus and Staphylococcus epidermidis biofilms. Antimicrob Agents Chemother. 2012;56(11):5804-10.

Smith-Palmer A, Stewart J, Fyfe L. Antimicrobial properties of plant essential oils and essences against five important foodborne pathogens. Lett Appl Microbiol. 1998;26(2):118-22.

Tekwu EM, Pieme AC, Beng VP. Investigations of antimicrobial activity of some Cameroonian medicinal plant extracts against bacteria and yeast with gastrointestinal relevance. $\mathrm{J}$ Ethnopharmacol. 2012;142(1):265-73.

Testore GP, Dori L, Buonomini AR, Schito GC, Soro O, Fortina $\mathrm{G}$, Andreoni S, et al. In vitro fluconazole susceptibility of 1565 clinical isolates of Candida species evaluated by the disk diffusion method performed using NCCLS M44-A guidelines. Diagn Microbiol Infect Dis. 2004;50(3):187-192.

Valarmathy K, Gokulakrishnan M, Kausar MS, Paul K. A study of antimicrobial activity of ethanolic extracts of various plant leaves against selected microbial species. Int J Pharm Sci Res. 2010;1(8):293-5. 
Vardar-Ünlü G, Silici S, Ünlü M. Composition and in vitro antimicrobial activity of Populus buds and poplar-type propolis. World J Microbiol Biotechnol. 2008;24(7):1011-7.
Vikram A, Jayaprakasha GK, Jesudhasan PR, Pillai SD, Patil BS.Suppression of bacterial cell-cell signalling, biofilm formation and type III secretion system by citrus flavonoids. J Appl Microbiol.2010;109(2):515-27.

Received for publication on $10^{\text {th }}$ February 2018 Accepted for publication on $23^{\text {rd }}$ September 2018 